\title{
The Pursuit of Financial Stability: Essays from the Federal Reserve Bank of Richmond Annual Reports
}

John A. Weinberg

I n 2007, as the financial system began to show strains stemming from mounting losses on mortgage-related securities, an often heard reassurance was that the banking system was well positioned to weather the storm. The regulatory capital of commercial banks at the end of 2007 was around 10 percent of assets, which was viewed as a cushion capable of absorbing all but the very worst shocks. But a combination of misplaced confidence in our capital regulation regime and the realization of shocks that were in fact worse than what was imagined in standard risk management exercises threw the financial system into deeper turmoil than we had seen in decades. By the end of 2008, losses at large commercial and investment banks had prompted the Federal Reserve and the Treasury to intervene at an unprecedented scale and scope, providing credit and capital support to a range of institutions.

The series of actions taken by the Fed and the government in the financial crisis are by now well-known - the subject of books and movies. In the thick of the crisis, these interventions were viewed as necessary to stop a free fall and restore confidence in financial intermediation. The crisis brought with it a deep recession followed by a slow recovery and a major legislative re-engineering of our approach to financial regulation.

The financial crisis could well prove to be the defining economic event for a generation of economists, as it raises fundamental questions

- The views expressed are those of the author and not necessarily those of the Federal Reserve Bank of Richmond or the Federal Reserve System. 
about the nature of financial fragility and the appropriateness of alternative policy responses. In particular, does financial intermediation, as it is practiced in modern economies, inevitably leave the economy subject to the potentially devastating effects of runs and fire sales? What are the characteristics of financial systems that create this fragility, and do those characteristics bring economic benefits that make them worth the risk? Much of the analysis of the financial crisis, as well as proposed policy responses, has been based on a presumption that financial instability is an inherent feature of a modern financial system. The policy implications of this view are that we should use regulation to do what we can to prevent crises. But this view also implies that when a crisis does occur, government or central bank financial support is necessary to keep a bad situation from getting worse.

At the Richmond Fed, both before and since the financial crisis, we have considered an alternative view, which focuses on the incentives created by the very government support that is often viewed as essential in the time of a crisis. Expectation of that support weakens the incentives of financial market participants to monitor and control risks. Broad belief in an extensive financial safety net, then, contributes to the creation and concentration of risks, making the financial system less stable. In 1999, Richmond Fed researchers attempted to assess the extent of the financial safety net and found that as much as 45 percent of financial sector liabilities were likely to enjoy perceived protection. ${ }^{1}$ So the period before the financial crisis is one in which the market's ability to discipline risk-taking by financial firms was potentially significantly diminished. To call this period a test of the effectiveness of unregulated financial markets - a test that markets failed - is an incomplete characterization. The pre-crisis period was only a test of the effectiveness of markets in which there is a significant expectation of government support in times of stress. This series of essays represents our exploration of the second of these interpretations, and what it implies about appropriate interventions by the government and the central bank.

The first essay from our 2008 Annual Report, by Aaron Steelman and John Weinberg, was written while the financial crisis was still unfolding. As such, it represents a preliminary look at the factors that may have contributed to the severity of the episode, with particular attention to the incentive effects of explicit and implicit government backing of parts of the financial sector. While in the heat of the moment, it was tempting to focus on the turmoil as it unfolded; we thought it was also important to examine the conditions that could give rise to

\footnotetext{
${ }^{1}$ Available at https://www.richmondfed.org/publications/research/special_reports/ safety_net.
} 
such tumult. Our focus on the financial safety net as a feature that can induce instability by weakening market discipline stood somewhat in contrast to a more prevailing view that instability, or systemic risk, was an inherent feature of financial markets.

In our 2009 Annual Report, Kartik Athreya took a deeper look at the concept of systemic risk. To the extent that market disruptions are possible, in which one firm's financial distress has spillover effects on the economy beyond the distressed firm's counterparties, interventions that limit the losses of a distressed firm's counterparties have the potential to ex post (after-the-fact) efficiency improving. The essay argues, however, that ex ante (before-the-fact) efficiency is ultimately a preferable criterion for making policy choices. And it is before a crisis occurs when the distortion of incentives from expected government protection is relevant.

In 2013, the centennial year of the Federal Reserve Act, our Annual Report placed the central bank's concern for financial stability into historical context. The essay, by Jeffrey Lacker and Renee Haltom, examines the origins of the Fed's lending powers, which have come to be a main tool for public sector intervention in times of financial distress. The authors argue that the original vision for Fed lending was as a tool for flexibly varying the supply of currency - something today we might think of more as the pursuit of monetary rather than financial stability. They argue that a financial stability mandate for the central bank, and an expectation that it will use its lending authority liberally in times of crisis, can lead to interventions that distort the allocation of credit among private market participants. And such credit allocation is more properly thought of as fiscal action, which should be avoided by a central bank with monetary policy independence. Further, the discretionary nature of such interventions can itself be a contributor to market uncertainty and instability.

The central problem of the financial safety net is that ex post intervention is hard to resist at the moment of crisis but, over time, has undesirable incentive effects. What policy steps can we then realistically hope will help us move away from an environment in which people perceive a broad and extensive financial safety net? This is the question taken up in our most recent essay. In our 2015 Report, Arantxa Jarque and David Price discuss one potentially fruitful avenue opened up by the Dodd-Frank Act. Title I of the Act created a requirement for large financial firms to draft and maintain resolution plans, or "living wills." Such a plan is intended to show the way to resolve a failing firm through unassisted bankruptcy, thereby making such a resolution viable. As of today, the task of crafting living wills that are viewed by the market as a viable way to resolve firms in distress remains a 
challenging one; however, with time and close collaboration between the firms and their regulators, living wills could become a powerful tool to diminish market participants' expectation of public sector assistance when one of these firms faces distress.

Taken together, these essays reflect much of the thinking we have done, some of it well before the financial crisis, on the sources of financial instability and the means by which public policy can promote stability. A unifying theme is that government interventions that protect creditors weaken the market discipline that might otherwise help to control risks in the financial system. This leaves us with recourse only to regulatory discipline. But as diligent and conscientious as we are in implementing financial regulation, our financial system will continue to face risks as financial market participants direct their innovative energies toward benefiting from perceived protection while circumventing regulatory controls. Ultimately, financial stability will be better served if we can scale back beliefs in a broad safety net and restore a measure of meaningful market discipline. 